\title{
An Engraved Caddo Vessel from the Quitman Area, Wood County, Texas
}

Timothy K. Perttula

Heritage Research Center, Stephen F. Austin State University

Kim Wright

Follow this and additional works at: https://scholarworks.sfasu.edu/ita

Part of the American Material Culture Commons, Archaeological Anthropology Commons, Environmental Studies Commons, Other American Studies Commons, Other Arts and Humanities Commons, Other History of Art, Architecture, and Archaeology Commons, and the United States History Commons

Tell us how this article helped you.

This Article is brought to you for free and open access by the Center for Regional Heritage Research at SFA ScholarWorks. It has been accepted for inclusion in Index of Texas Archaeology: Open Access Gray Literature from the Lone Star State by an authorized editor of SFA ScholarWorks. For more information, please contact cdsscholarworks@sfasu.edu. 


\section{An Engraved Caddo Vessel from the Quitman Area, Wood County, Texas \\ Creative Commons License \\ (c) $($ ) $(9)$}

This work is licensed under a Creative Commons Attribution-NonCommercial 4.0 International License 


\title{
An Engraved Caddo Vessel from the Quitman Area, Wood County, Texas
}

\author{
Timothy K. Perttula and Kim Wright
}

\section{INTRODUCTION}

Pottery vessels from ancestral Caddo sites are widely known across all parts of East Texas, with recognizable vessel forms and decorative styles that have both distinctive temporal and spatial distributions (Perttula 2013; Suhm and Jelks 1962). In this article we put on record an engraved Caddo vessel with a rather unique design from an unknown site in the Quitman area in Wood County.

This part of East Texas, specifically the Lake Fork Creek basin in the upper Sabine River drainage, is an area with an extensive record of ancestral Caddo habitation sites and cemeteries (Bruseth and Perttula 1981; Cast et al. 2006; Crane 1982; Jackson 1930; Perttula 2004, 2005, 2012; Perttula et al. 1993, 2007, 2009). In particular, there are many Late Caddo period, Titus phase, sites and family cemeteries dating from approximately 330 to 580 years ago (A.D. 1430-1680) known in this area. The Caddo vessel described herein is thought to come from an unknown Titus phase cemetery in this area.

\section{DISCOVERY OF THE VESSEL}

The Caddo vessel was acquired by the junior author's mother-in-law probably in 1930. At that time she was a school teacher in Quitman, Texas, in Wood County, and a student brought the pottery vessel to school one day. She either paid the student a small amount for the vessel or he gave it to her. The circumstances of how the vessel was found in the first place are not clear, but it may have been plowed up by the student's father. Many Caddo sites were found in just this way back in the Depression, as the county records at the Texas Archeological Research Laboratory at The University of Texas at Austin can attest.

\section{VESSEL DESCRIPTION}

The vessel is an olla, or short-necked bottle (Figure 1a-b). It stands $14.0 \mathrm{~cm}$ in height, and its maximum body width is also $14.0 \mathrm{~cm}$. At the neck it is $5.1 \mathrm{~cm}$ in diameter and the neck walls are $3.1 \mathrm{~mm}$ in thickness. The basal diameter is $5.4 \mathrm{~cm}$. The light oxidized colors of the interior and exterior surfaces, and the dark vessel core, suggests the vessel was fired in a low oxygen environment, but left to cool in the open air (see Teltser 1993), leaving thin oxidized surfaces in the vessel core. Most of the Caddo pottery in East Texas is fired in this manner (see Perttula 2013). The vessel was tempered with finely ground up pieces of grog or crushed sherds.

The olla has a very distinctive engraved design on the vessel body, outlined by single horizontal engraved lines below the neck and mid-way down the body. The principal decorative element is an engraved oval with an eye element within it; one corner of each eye has a few hatched lines (see Figure 1a). These oval eye elements are in four panels divided by hatched and cross-hatched ladders as well as curvilinear, and semi-circular zones and hatched triangles (see Figure 1b).

There are two carinated bowls known in the Gregg County Historical Museum East Texas Caddo vessel collection that have the same oval-shaped engraved eye element as the engraved olla from the Quitman area. 


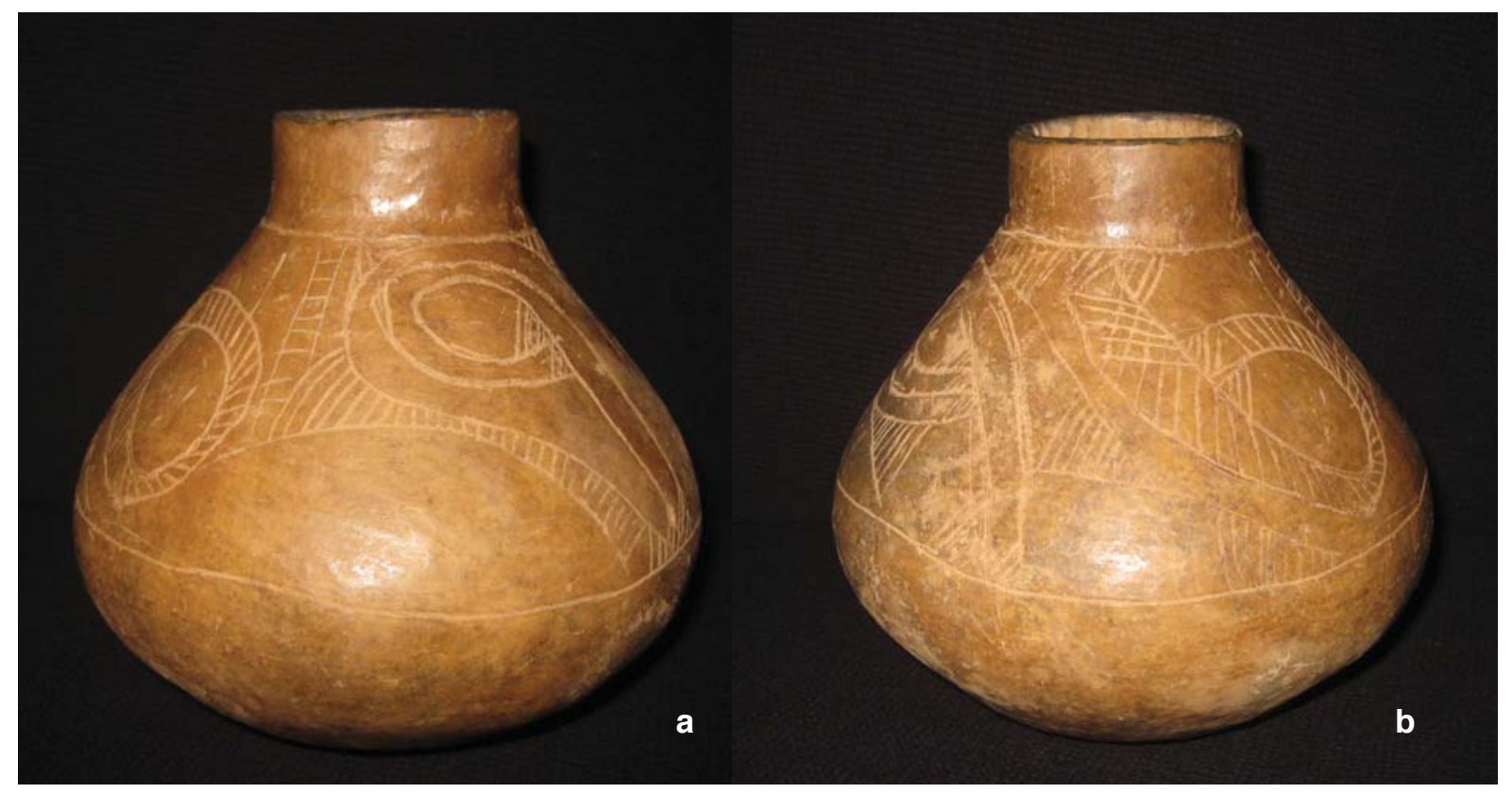

Figure 1. Two views of the engraved olla from the Quitman area: a, first view; b, second view.

This includes a Late Caddo, Titus phase Ripley Engraved carinated bowl with engraved ovals with excised eye elements, and adjacent engraved triangle elements with negative ovals (Perttula et al.2014:Figure 33d), and a carinated bowl with oval eye-shaped engraved elements below a series of horizontal engraved lines around the rim (Perttula et al. 2014:Figure 79d). Another Caddo vessel with an engraved eye element is on a carinated bowl from the $18^{\text {th }}$ century Kinsloe phase Millsey Williamson site (41RK3) in the mid-Sabine River basin (see Perttula and Nelson 2014). The rim panel on this vessel has sets of opposed engraved oval eye motif repeated four times around the vessel; the oval eyes are connected by a rectangular excised element. The sets of eye elements are separated by nested triangles with negative ovals and hooked arm elements (Perttula and Nelson 2014:Figures 4 and 5a). Recently, another vessel with the engraved eye element has been reported from a Titus phase site in the upper Cypress Creek basin at Lake Bob Sandlin (Bo Nelson, personal communication, September 30, 2013).

\section{CONCLUSIONS}

The engraved olla from an unknown ancestral Caddo site in the Quitman area of Wood County, in East Texas, has a distinctive engraved oval eye element. This particular element has rarely been identified and documented in East Texas Caddo vessel assemblages, but the few vessels that we are aware of have been found in cemeteries in the mid- and upper Sabine River basin and the upper Cypress Creek basin that date after ca. A.D. 1430 to as late as the early $18^{\text {th }}$ century A.D. Given the number of known post-A.D. 1430 Titus phase cemeteries in the Lake Fork Creek drainage in the Quitman area, and the stylistic similarity of the engraved eye element to other sites with Titus phase vessels, it is considered likely that the engraved olla described herein also comes from a Titus phase cemetery in this part of East Texas.

\section{REFERENCES CITED}

Bruseth, J. E., and T. K. Perttula

1981 Prehistoric Settlement Patterns at Lake Fork Reservoir. Texas Antiquities Permit Series, Report No. 2. Texas Antiquities Committee and Southern Methodist University, Austin and Dallas. 
Cast, R., T. K. Perttula, B. Gonzalez, and B. Nelson

2006 Documentation of Caddo Ceramic Vessels from 41WD60, Wood County, Texas. Historic Preservation Program, Caddo Nation of Oklahoma, Binger, Oklahoma.

Crane, C. J.

1982 Plant Utilization at Spoonbill, an Early Caddo Site in Northeast Texas. Midcontinental Journal of Archaeology 7(1):81-97.

Jackson, A. T.

1930 Notes on Field Work, Minnie Garrison Farm, Wood County, Texas. MS on file, Texas Archeological Research Laboratory, The University of Texas at Austin.

Perttula, T. K.

2004 The Prehistoric and Caddoan Archeology of the Northeast Texas Pineywoods. In The Prehistory of Texas, edited by T. K. Perttula, pp. 370-407. Texas A\&M University, College Station.

2005 The M. W. Burks Site (41WD52), A Late Caddo Hamlet in Wood County, Texas. Journal of Northeast Texas Archaeology 23:1-27.

2012 Analysis of Ceramic Sherds from the Mid- $18^{\text {th }}$ Century Gilbert Site on Lake Fork Creek, Rains County, Texas. Journal of Northeast Texas Archaeology 37:1-22.

2013 Caddo Ceramics in East Texas. Bulletin of the Texas Archeological Society 84:181-212.

Perttula, T. K. and B. Nelson

2014 The Millsey Williamson (41RK3), Bead Burial, and L. N. Morwell Farm Sites on Martin Creek: Historic Caddo Settlements along Trammels Trace, Rusk County, Texas. Journal of Northeast Texas Archaeology 44:23-46.

Perttula, T. K., R. Z. Selden, Jr., and B. Nelson

2014 A Catalog of Selected Caddo Ceramic Vessels in the Buddy Jones Collection at the Gregg County Historical Museum. Special Publication No. 30. Friends of Northeast Texas Archaeology, Pittsburg and Austin.

Perttula, T. K., B. D. Skiles, and B. C. Yates

1993 The Goldsmith Site (41WD208): Investigations of the Titus Phase in the Upper Sabine River Basin, Northeast Texas. Bulletin of the Texas Archeological Society 61:139-191.

Perttula, T. K., M. Walters, S. Marceaux, and B. Nelson

2009 Caddo Pottery Vessels and Pipes from Sites in the Middle and Upper Sabine and Upper Neches River Basins, Smith and Wood Counties, Texas. Special Publication No. 7. Friends of Northeast Texas Archaeology, Pittsburg and Austin.

Perttula, T. K., M. Walters, R. Cast, B. Gonzalez, and B. Nelson

2007 Documentation of Funerary Offerings from a Prehistoric Caddo Burial at Site 41 WD244, Wood County, Texas. Caddo Nation of Oklahoma and Archeological \& Environmental Consultants, LLC, Binger and Austin.

Suhm, D. A., and E. B. Jelks (editors)

1962 Handbook of Texas Archeology: Type Descriptions. Special Publication No. 1, Texas Archeological Society, and Bulletin No. 4, Texas Memorial Museum, Austin. Reprinted in 2009, Gustav's Library, Davenport, Iowa.

Teltser, P. A.

1993 An Analytic Strategy for Studying Assemblage-Scale Ceramic Variation: A Case Study from Southeast Missouri. American Antiquity 58(3):530-543. 